\title{
ARNT2 Gene
}

National Cancer Institute

\section{Source}

National Cancer Institute. ARNT2 Gene. NCI Thesaurus. Code C26374.

This gene plays a regulatory role in transcription in response to developmental and environmental stimuli. 